\title{
Civil War, Ethnicity, and the Migration of Skilled Labor
}

by

\author{
James T. Bang
}

Aniruddha Mitra

October 2010

MIDDLEBURY COLLEGE ECONOMICS DISCUSSION PAPER NO. 10-34

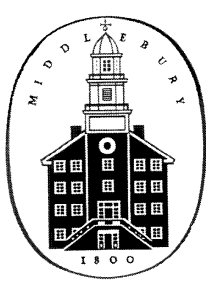

DEPARTMENT OF ECONOMICS

MIDDLEBURY COLLEGE

MIDDLEBURY, VERMONT 05753

http://www.middlebury.edu/ econ 


\title{
Civil War, Ethnicity, and the Migration of Skilled Labor
}

\author{
James T. Bang \\ Department of Economics \\ Virginia Military Institute \\ 342 Scott Shipp Hall \\ Lexington, VA 24450 \\ bangjt@vmi.edu \\ Aniruddha Mitra \\ Department of Economics \\ Middlebury College \\ 504 Warner Hall \\ Middlebury, VT 05753 \\ amitra@middlebury.edu
}

\section{August 2010}

\begin{abstract}
We investigate the impact of civil war on high skilled emigration rates to the OECD over the period 1985-2000. Controlling for economic and institutional characteristics of source countries, we find that civil war increases high skilled emigration by about 5 percent on the average. However, the nature of conflict matters: While brain drain from countries with ethnic conflict is about 6-8 percent greater on average than it is from countries without conflict, brain drain from countries with nonethnic conflict is less, and statistically insignificant. Duration also matters: Each additional year of ethnic conflict worsens the brain drain by between 0.4 and 1 percent, whereas the effect of an additional year of nonethnic conflict is small and insignificant.
\end{abstract}




\section{Introduction}

The last decade and a half has seen the emergence of a vast literature on the causes and consequences of brain drain or the migration of tertiary skilled labor (Commander et al., 2004; Docquier et al., 2008). Yet the role of conflict as a determinant of skilled migration remains relatively unexplored. This paper investigates the impact of internal conflict or civil war in the countries of origin on the magnitude of brain drain to the OECD at five-year intervals over the period 1985-2000. Controlling for economic and institutional characteristics of source countries, we find that civil war increases high skilled emigration on the average. Further, the consequences of civil war on the migration of tertiary skilled labor depend critically on the type of conflict being experienced in the country of origin: While ethnic civil war increases the fraction of tertiary skilled emigrants, nonethnic civil war has no significant impact on the extent of brain drain. In exploring reasons behind the differential impact on selection, we find that it is primarily due to the fact that the ethnic civil wars tend to last longer on the average than nonethnic wars. Interestingly, even though nonethnic wars exhibit a greater intensity of violence in our sample, this does not translate into a significant impact of nonethnic conflict on brain drain.

In providing a more nuanced analysis of the role of internal conflict on skilled migration, our study contributes to the literature that investigates the causes and consequences of brain drain. In addition, given the importance of skilled diasporas in bringing about the resolution of conflict as also helping the reconstruction of an economy after years of civil war, it helps understand how migration policy in developed nations can serve the cause of peace. Lastly, it contributes to the emerging literature on conflict that calls for the recognition of ethnic conflict as a separate conceptual category because it emerges from different motivations and has different consequences than other forms of political violence. 


\section{Conceptual Preliminaries}

An emerging interdisciplinary literature urges the recognition of ethnic and nonethnic conflict as distinct phenomena. ${ }^{1}$ There is considerable evidence that ethnic civil wars tend to be of greater duration (Kirschner, 2009); exhibit a greater probability of recurrence (Kreutz, 2010); lead to a greater intensity of violence; and bear a greater risk of escalation (Eck, 2009) than civil wars erupting along schisms other than ethnicity. In addition, it has been argued that ethnic and nonethnic conflict may arise due to different causes (Sambanis, 2001; Reynal-Querol, 2002). As such, it is worth investigating if the two types of civil war differ in their consequences on economic outcomes; in our case, the migration of highly skilled labor. Specifically, we explore the hypothesis that ethnic civil wars may lead to greater migration of highly skilled labor, on the average, than nonethnic civil wars.

The underlying rationale is simple: Internal conflict reduces expected returns to educational investment and hence provides an incentive to migrate for individuals who have already undertaken the investment in education. If ethnic conflict lasts longer than nonethnic conflict on the average, then controlling for the intensity of violence, it is likely to reduce the expected returns to education more permanently than nonethnic conflict. Hence, a society experiencing ethnic civil war is likely to suffer a greater magnitude of brain drain on the average than one with nonethnic civil war.

Any empirical inquiry into the causes and consequences of civil war faces the problem that the literature is hardly unanimous on the operational definition of the phenomenon. Most studies are, however, based on one of two identification criteria extant in the literature, namely that of

\footnotetext{
${ }^{1}$ See the references in Eck (2009). For an argument against the separation of ethnic and nonethnic conflict, see King (2001).
} 
the Uppsala Conflict Data Program (UCDP) (Gleditsch et al., 2002) and that of the Political Instability Task Force (PITF). To establish the robustness of our results, we adopt both of these definitions. As per the identification criteria proposed by UCDP, a civil war is a contested incompatibility between the government of a state and one or more internal opposition groups with or without external intervention that concerns either government or territory or both and where the use of armed force results in at least 25 battle related deaths per year. ${ }^{2}$ This yields 51 country-years of civil war over our sample period $1985-2000 .^{3}$ For an episode of political violence to be counted as a civil war by PITF, however, it must occur between the government of a sovereign state and either political or ethnic challengers internal to the state. Further, 'each party must mobilize 1000 or more people .... and there must be at least 1000 direct conflictrelated deaths over the full course of the armed conflict and at least one year when the annual conflict-related death toll exceeds 100 fatalities. ${ }^{4}$ This yields 48 country-years of civil war over the period of interest.

An even greater concern relates to the definition of an ethnic civil war. The PITF State Failure Problem Set explicitly distinguishes between ethnic and nonethnic or revolutionary wars, where the former comprise 'episodes of violent conflict between governments and national, ethnic, religious, or other communal minorities (ethnic challengers) in which the challengers seek major changes in their status.' Revolutionary wars, on the other hand, occur 'between governments and politically organized groups (political challengers)... that seek to overthrow the central government, to replace its leaders, or to seize power in one region.' Based on the

\footnotetext{
2 This includes the categories internal armed conflict and internationalized internal armed conflict in the UCDP/PRIO Armed Conflict Dataset. For more information, refer to the codebook available at the UCDP webpage: http://www.pcr.uu.se/research/UCDP/data_and_publications/datasets.htm

${ }^{3}$ Recall that our sample is defined at five year intervals, not annually.

${ }^{4}$ This includes the categories revolutionary war and ethnic war in the PITF State Failure Problem Set. For more information, consult the codebook at http://www.systemicpeace.org/inscr/inscr.htm
} 
PITF classification, we have 37 country- years of ethnic war and 11 country-years of nonethnic war over our sample period.

The PITF definition of ethnic civil war relies explicitly of the identification of ethnic affiliations of participants. However, given the problem of changing group boundaries over time, identifying an ethnic group may be problematic (Fearon, 2003). As an alternative, Fearon and Laitin (2003) focus on the more easily observed process of mobilization: Thus, an ethnic war is any civil war where contestants mobilize either partially or entirely along the lines of ethnicity. Following Eck (2009), we apply the criterion of Fearon and Laitin (2009) to disaggregate the UCDP dataset which otherwise does not distinguish between civil wars by type. This gives us 40 country- years of ethnic war and 11 country-years of nonethnic war over our sample period.

\section{Empirical Model and Data}

To measure the impact of civil war on the emigration of high skilled labor, we estimate the following equation:

(1) high skill it $=X \beta+Z \gamma+e_{i}$.

The dependent variable high-skill ${ }_{i t}$ denotes the fraction of highly skilled or tertiary educated immigrants from country $i$ in year $t$. Data on this variable come from Defoort (2006), who provides information on the stocks of primary, secondary, and tertiary educated foreign born populations in the OECD from 194 source countries. While these data are available at five-year intervals over 1975-2000, limitations in the availability of explanatory variables restrict our sample to an unbalanced panel covering the period 1985-2000.

The matrix of controls $X$ includes constant terms that capture both region and year specific fixed effects and a set of source country characteristics commonly used in the brain drain literature, such as GDP per capita and its square, population, and the CPI inflation rate from the 
World Development Indicators (WDI); and the total foreign born population in the OECD from a given source country in a given year from Defoort (2006).

Since the impact of conflict on migrant selection may be confounded by the influence of poor institutions, we also control for institutional quality in the source countries. To capture the multidimensionality of political institutions while still avoiding the problem of multicollinearity, we perform an exploratory factor analysis on 13 separate measures of institutional quality. These include indices of corruption, bureaucratic quality, democratic accountability, government stability, and investment profile taken from the International Country Risk Guide (ICRG); legislative and executive indices of electoral competition, the political fractionalization index, the political polarization index, the index of electoral fraud, and the number of checks and balances that exist within government taken from the Database of Political Institutions (DPI); and the democracy-autocracy index and regime durability taken from the Polity IV Project. ${ }^{5}$ As reported in Table 2, three distinct factors emerge from this analysis: Democracy, which is primarily composed of the legislative and electoral indices of electoral competition, the democracy-autocracy index, the number of checks and balances in the government, the index of democratic accountability, and the indices of political fractionalization and polarization; transparency of government operations, which includes the indices of corruption and bureaucratic quality, regime durability, and the absence of electoral fraud); and credibility of the government, which is primarily composed of the investment profile index and the index of government stability. These three factors are included as controls in our regression.

Finally, the matrix $Z$ contains variables that describe civil wars which may be taking place in a given source country in a given year. Depending on the particular aspect of internal conflict we

\footnotetext{
${ }^{5}$ See Bang and Mitra (2010) for a comprehensive description of the methodology and a discussion of alternative approaches to addressing the multidimensionality of institutional structure.
} 
wish to explore, this matrix may include a simple dummy for the presence of civil war in general; separate dummy variables for the presence of ethnic and nonethnic civil war; duration of the conflict measured in years; and the intensity of violence measured both by an index and the number of battle related deaths in a given country in that year. As mentioned in Section 2, given the lack of consensus regarding the definition of civil war, and even more critically, the caveats associated with identifying a civil war as ethnic; the conflict variables are taken from two alternative datasets, developed by the Political Instability Task Force (PITF) and the Uppsala Conflict Data Program (UCDP) respectively. Since both datasets as also the underlying conceptual issues have been introduced in the previous section, we shall conclude the description of our data at this point, referring the reader to Table 1 for summary statistics of the variables.

One problem that may arise in estimating equation (1) using the classical regression model is the fact that GDP per capita may be endogenous, and may, in fact, depend on some of other factors that are of interest in explaining the brain drain, notably the institutional variables (Knack

and Keefer, 1995; Alesina et al., 1996). To address this, we estimate (1) using a generalized method of moments (GMM) procedure, with per capita energy consumption from the WDI as an excluded instrument for per capita GDP.

\section{Results and Robustness}

As a first look at the data, we consider the effect of the ordinary presence of civil war in a given country in a given year on the fraction of tertiary educated emigrants. Columns 1 and 2 of Table 3 report our initial results with the PITF and UCDP data, respectively. The presence of civil war is seen to increase the fraction of tertiary educated emigrants by about $5 \%$ when we use 
the PITF data and by about $7 \%$ when we use the UCDP data, and the impact for each is significant at the 0.05 level. As noted previously, however, our initial investigation may not reveal the full impact of certain types of civil war because the consequences of internal conflict could depend critically on the nature of conflict in question. Indeed, the results presented below confirm our hypothesis that ethnic conflict has far more dire consequences on the migration of highly skilled labor.

As a second step in our analysis, therefore, we differentiate civil war by type. Including separate dummy variables for the two types of civil war based on the PITF criterion for ethnic civil war (Sambanis, 2001; Reynal-Querol, 2002), we find that the presence of ethnic conflict increases the fraction of tertiary educated emigrants by about $6 \%$ and the effect is significant at the 0.10 level. Nonethnic conflict also increases the fraction of tertiary educated emigrants, but by just about $3 \%$ and its impact is statistically insignificant. The results of this exercise are reported in Column 3 of Table 3. We subsequently replicate our results using the identification criterion proposed by Fearon and Laitin (2003), whereby an ethnic civil war is one where actors mobilize along the lines of ethnicity. Following Eck (2009), we first achieve a separation of the UCDP data into episodes of ethnic and nonethnic civil war and then include separate dummy variables based on the disaggregated UCDP data. As seen from Column 4 of Table 3, the presence of ethnic conflict in a country increases the fraction of tertiary educated emigrants to the OECD by about $8 \%$ and the effect is significant at the 0.05 level. By contrast, the presence of nonethnic conflict increases the fraction of tertiary educated emigrants by about $4 \%$ and the effect is statistically insignificant.

As mentioned in Section 2, ethnic civil wars exhibit a different structure of violence than nonethnic civil wars in that they tend to last longer; and controlling for duration, may exhibit a greater intensity of violence, even though this last is not seen in our sample. Given the presence 
of civil war, the average ethnic war in our sample period 1985-2000 lasts about 19 years based on the Fearon and Laitin (2003) criterion and 10 years based on the PITF criterion. By contrast, the average nonethnic war lasts about 17 years based on the Fearon and Laitin (2003) criterion and about 8 years using the PITF criterion. ${ }^{6}$ With respect to intensity, however, the average ethnic war in our sample causes about 2,600 battle-related fatalities per year, whereas the average nonethnic war causes about 4,720 fatalities, based on version 3.0 of the PRIO Battle Deaths Dataset (Lacina and Gleditsch, 2005) that covers cases of conflict included in the UCDP/PRIO Armed Conflict Dataset. It is, therefore, natural to ask how the aspects of duration and intensity account for the difference in the impact of ethnic and nonethnic conflict on selection. To address this, we first consider the impacts of duration and intensity in isolation and then take up both aspects simultaneously in the same model.

The next step in our analysis is, therefore, to introduce separate measures of duration for ethnic and nonethnic civil war as captured by the number of years since the onset of the current conflict. The coefficients on these variables are interpreted as the marginal effects of an additional year of ethnic or nonethnic conflict on the fraction of tertiary educated emigrants, given that the country is already experiencing the relevant type of civil war. Columns 5 and 6 of Table 3 report the results of this exercise with the PITF and UCDP data, respectively: Based on the former, an additional year of ethnic conflict is seen to increase the fraction of tertiary educated emigrants by almost $1 \%$ and the impact is significant at the 0.05 level. An additional year of nonethnic conflict, by contrast, is seen to have a modest negative effect, even though the coefficient is statistically insignificant. With the UCDP data, an additional year of ethnic conflict is seen to increase the fraction of tertiary educated emigrants by about $0.4 \%$ and the result is

\footnotetext{
${ }^{6}$ This conditional mean can be calculated by dividing the mean duration of ethnic (nonethnic) conflict for the entire sample by the proportion of countries experiencing ethnic (nonethnic) conflict.
} 
significant at the 0.10 level, while an additional year of nonethnic conflict now has a positive though smaller and insignificant impact. Interestingly, the coefficient on the presence of ethnic conflict turns negative for the PITF dataset when we introduce duration into the model, although the negative impact is small, and statistically insignificant. For the UCDP dataset, the effect of the onset of ethnic war remains positive, but here too the effect is small and insignificant. To sum up, therefore, the duration of ethnic conflict has a significant positive impact on the migration of high skilled labor but the duration of nonethnic conflict plays little or no role.

We now take up the question of intensity in isolation to the duration of civil war. The PITF dataset provides three indices of intensity based on the annual number of battle related fatalities; the number of rebel combatants; and the part of the country affected by violence, respectively. ${ }^{7}$ Since the UCDP dataset also reports intensity levels based on fatalities, the results presented in Column 7 of Table 3 are based on the first index, even though the results are robust to the use of the other two indices of intensity. ${ }^{8}$ As before, the presence of nonethnic conflict has a significant positive impact and an additional battle death from nonethnic conflict has a significant negative impact on brain drain at the 0.05 level. In this case, however, neither an additional battle death from ethnic conflict nor its ordinary presence has a significant impact on selection. To sum up, the intensity of nonethnic conflict has a significant negative impact on the migration of high skilled labor but the intensity of ethnic conflict plays little or no role.

The UCDP dataset measures the intensity of ethnic and nonethnic civil war, using the annual number of battle related deaths from version 3.0 of the PRIO Battle Deaths Dataset (Lacina and Gleditsch, 2005). The coefficients on these variables are interpreted as the marginal effects of an

\footnotetext{
${ }^{7}$ The fatality index (MAGFIGHT) used in this paper takes the value 0 for less than 100 fatalities; 1 for $100-1000$ fatalities; 2 for 1000-5000 fatalities; 3 for 5000-10,000 fatalities; and 4 if the number of battle related deaths exceed 10,000 . The index is assigned a value 9 in the absence of information on casualty figures. See page 8 of the PITF Problem Set Codebook for this and the other indices MAGFIGHT and MAGAREA.

${ }^{8}$ The calculations are available on request.
} 
additional death from the relevant type of conflict on the fraction of tertiary educated emigrants. As seen from Column 8 of Table 3, the presence of both ethnic and nonethnic conflict has a significant positive impact on selection at the 0.05 level. However, while the impact of an additional battle death is weak and insignificant for ethnic conflict, an additional battle death from nonethnic conflict has a significant negative impact on selection at the 0.10 level.

This begs the question as to why do we see a significant negative impact of intensity on brain drain for nonethnic conflict when the intensity of ethnic conflict has a weakly positive impact. A reason for this could be that ethnic and nonethnic conflict give rise to different expectations on the part of educated elites, who play a vital role in mobilizing the population for conflict (Horowitz, 2000). It has been argued that nonethnic conflict arises due to economic grievances, either over the lack of economic opportunities or over the division of social surplus (Sambanis, 2001). Given that civil war is generally observed in societies with weak governments, an increase in the intensity of revolutionary conflict may signify an escalation involving greater mobilization on the part of the rebel. This will increase the probability of success for elites responsible for mobilization and consequently, give them less incentive to migrate. Ethnic conflict, on the other hand, often takes the form of deliberate coercion of ethnic minorities and it is often the case that educated elites suffer disproportionately more (Docquier and Rapoport, 2003). Hence, an increase in duration or intensity of ethnic violence may increase the incentive to migrate for the highly skilled. However, the effect is weak, given that it also the case that ethnic elites may willfully manipulate the rank and file into conflict to pursue their own instrumental needs.

As a final exercise, we include both the duration and the intensity dimension in a single model, presented in Columns 9 and 10 for the PITF and UCDP data respectively. With the PITF data, we find that an additional year of ethnic conflict increases the fraction of tertiary educated 
emigrants by about $0.1 \%$ and the result is significant at the 0.05 level, while an additional year of nonethnic conflict has a statistically insignificant impact. While an additional battle death from ethnic conflict has an insignificant positive impact on selection, an additional battle death from nonethnic conflict has a negative impact at the 0.10 level. Using the UCDP data again gives us a positively significant impact of an additional year of ethnic conflict at the 0.10 level; an insignificant negative impact of an additional year of nonethnic conflict; an insignificant impact of an additional battle death from ethnic civil war; and a significant negative impact of an additional battle death from nonethnic war at the 0.05 level. The mere presence of ethnic conflict is now seen to have a negative impact at the 0.10 level of significance, but the marginal significance of this effect as also its lack of robustness prevents it from being too much of a departure from what we observed before.

In summation, therefore, it appears that the duration of ethnic conflict has a much greater impact on selection than its intensity. In fact, it seems that the significant difference between the impact of ethnic and nonethnic conflict on the magnitude of brain drain is, to a great extent, driven by the fact that the ethnic civil wars last longer on the average than nonethnic ones, even though the latter may be associated with greater levels of violence.

It should also be mentioned that the signs and significances of the control variables remain robust to changes in the source of conflict data and specifications of the empirical model: Institutional quality as captured by the extent of democracy remains negatively significant, supporting the hypothesis that lower institutional quality increases the incentives for the highly skilled to migrate (Bang and Mitra, 2010). Average educational attainment in the source country remains positively significant on the whole, again in line with the existing literature. Lastly, the stock of foreign born population in the OECD from a particular country remains negatively significant, confirming recent evidence that diasporas may have a negative impact on selection 
(Docquier et al., 2010). Interestingly, neither GDP nor its square shows up as significant in any of the specifications.

\section{Conclusion}

This paper investigated the impact of civil war on the magnitude of brain drain from a country. Specifically, we explored the hypothesis that the root of conflict is important and ethnic conflict may have far more serious consequences on the migration of skilled labor than nonethnic conflict. Our analysis confirmed that this is indeed the case: While ethnic conflict was seen to have a significant positive impact on selection, there was weak evidence that nonethnic conflict may, in fact, have a negative impact. Further, the duration of ethnic conflict proved to be important, each additional year of this type of civil war increasing the fraction of highly skilled emigrants by $0.7 \%$ at a minimum. However, the intensity of ethnic conflict turned out to have no appreciable impact on the migration of highly skilled labor. The results proved robust both to alternative definitions of civil war and to alternative conceptions of ethnic conflict.

Our study helps to shed light on the relatively unexplored phenomenon of migration from societies in conflict. In emphasizing the caveats to considering civil war as a unified phenomenon, it provides a more nuanced analysis of the role of conflict as a determinant of skilled migration; and at least partially, helps to explain why studies based on the conception of civil war as a unified category may have failed to obtain a robust impact of internal conflict on the magnitude of brain drain (Beine et al., 2008). Lastly, our study brings up an interesting policy question: Given the significant difference in the impact of ethnic and nonethnic conflict on the structure of migration, should migration policy in host countries be sensitive to the nature of conflict raging in the countries of origin? The ethical dilemma aside, if skilled migration has a beneficial impact on the host country, it may be in the best interest of the latter to pursue a less 
restrictive migration policy towards a country plagued by ethnic conflict than one experiencing nonethnic civil war. Further, given the role of skilled diasporas in directing foreign direct investment to the countries of origin; facilitating transfers of technology; and ushering in needed institutional reform; a more favorable migration policy towards countries experiencing ethnic war may significantly help post conflict recovery, especially since the devastation from ethnic conflict is considerably greater than other forms of civil war. These and other questions comprise important areas of inquiry for further research. 


\section{Bibliography}

Alesina, A., Ozler, S., Roubini, N., and P. Swagel, (1996), Political instability and economic growth, Journal of Economic Growth 1, 189-211.

Bang, J.T. and A. Mitra, (2010), Brain Drain and Institutions of Governance: Educational Attainment of Immigrants to the US 1988-1998, Department of Economics Working Paper Series No. 1026, Middlebury College.

Beine, M., Docquier, F., and C. Ozden, (2010), Diasporas, Journal of Development Economics, forthcoming.

Beine, M., Docquier, F., and M. Schiff, (2008), Brain Drain and its Determinants: A Major Issue for Small States, IZA Discussion Papers 3398, Institute for the Study of Labor (IZA).

Commander, S., Kangasniemi, M., and L. A. Winters, (2004), The brain drain: curse or boon? A survey of the literature, in R. E. Baldwin and L. A. Winters (eds.) Challenges to Globalization: Analyzing the Economics, Chicago: Chicago University Press, 235-272.

Docquier, F. and Rapoport, H., (2003), Ethnic discrimination and the migration of skilled labour. Journal of Development Economics, 70, 159-72.

Eck, K., (2009), From Armed Conflict to War: Ethnic Mobilization and Conflict Intensification, International Studies Quarterly 53, 369-388.

Esteban, J. and D. Ray, (2008), On the Salience of Ethnic Conflict, American Economic Review 98(5), 2185-2202.

Fearon, J. D., (2003), Ethnic and Cultural Diversity by Country, Journal of Economic Growth 8, 195-222.

Fearon, J. D. and D. D. Laitin, (2003), Ethnicity, Insurgency, and Civil War, American Political Science Review 97(1), 75-90.

Gleditsch, N. P., Wallensteen, P., Eriksson, M., Sollenberg, M. \& H. Strand, (2002), Armed Conflict 1946-2001: A New Dataset, Journal of Peace Research 39(5), 615-637, Version 4

Horowitz, Donald L., (2000), Ethnic Groups in Conflict, Berkeley and Los Angeles, CA: University of California Press.

King, C., (2001), The Myth of Ethnic Warfare: Understanding Conflict in the Post-Cold War World, Foreign Affairs 80 (6), 165-170.

Kirschner, S. A., (2009), Families and Foes: Ethnic Civil War Duration, Doctoral Thesis, Department of Political Science, University of Michigan. 
Knack, S. and P. Keefer, (1995), Institutions and Economic Performance: Cross-Country Tests Using Alternative Institutional Measures, Economics and Politics 7 (3), 207-227.

Kreutz, J., (2010), How and When Armed Conflicts End: Introducing the UCDP Conflict Termination Dataset, Journal of Peace Research 47(2), 243-250.

Lacina, B. \& N. P. Gleditsch, (2005), Monitoring Trends in Global Combat: A New Dataset of Battle Deaths, European Journal of Population 21(2-3), 145-166.

Reynal-Querol, M., (2002), Ethnicity, Political Systems, and Civil War, Journal of Conflict Resolution 46(1), 29-54.

Sambanis, N., (2001), Do ethnic and nonethnic civil wars have the same causes? A theoretical and empirical inquiry (part I), Journal of Conflict Resolution 45(3), 259-282. 
Tables

Table 1: Summary Statistics

\begin{tabular}{lcrrrrr}
\hline Variable & Source & \multicolumn{1}{l}{ Obs } & \multicolumn{1}{l}{ Mean } & Std. Dev. & Min & \multicolumn{2}{l}{ Max } \\
\hline High-Skill Emigration & Defoort & 1,160 & 0.396 & 0.139 & 0.062 & 0.739 \\
Real GDP per capita (\$1,000) & WDI & 936 & 5.355 & 7.938 & 0.056 & 46.606 \\
Ethnic Conflict & PITF & 1,160 & 0.095 & 0.293 & 0 & 1 \\
Ethnic Conflict Duration & PITF & 1,160 & 0.966 & 3.906 & 0 & 40 \\
Nonethnic Conflict & PITF & 1,160 & 0.034 & 0.183 & 0 & 1 \\
Nonethnic Conflict Duration & PITF & 1,160 & 0.286 & 1.954 & 0 & 30 \\
Ethnic Conflict & UCDP & 1,160 & 0.104 & 0.306 & 0 & 1 \\
Ethnic Conflict Duration & UCDP & 1,160 & 1.991 & 7.341 & 0 & 55 \\
Ethnic Conflict Battle Deaths & UCDP & 1,160 & 270.674 & $1,953.391$ & 0 & 36,250 \\
Nonethnic Conflict & UCDP & 1,160 & 0.036 & 0.187 & 0 & 1 \\
Nonethnic Conflict Duration & UCDP & 1,160 & 0.610 & 3.739 & 0 & 41 \\
Nonethnic Conflict Battle Deaths & UCDP & 1,160 & 170.899 & $2,814.326$ & 0 & 65,000 \\
Inflation (CPI) & WDI & 795 & 56.526 & 521.753 & -4 & 11,750 \\
Population (millions) & WDI & 1,113 & 26.500 & 0.010 & 0 & 1,260 \\
Total Emigrants (millions) & Defoort & 1,160 & 1.831 & 12.800 & 0 & 177 \\
Average Years of Education & Barro \& Lee & 668 & 5.194 & 2.917 & 0.140 & 12.250 \\
Government Stability & ICRG & 508 & 7.093 & 2.375 & 0 & 12 \\
Investment Profile & ICRG & 508 & 6.225 & 2.138 & 0 & 0 \\
Corruption & ICRG & 508 & 3.282 & 1.391 & 0 & 6 \\
Bureaucratic Quality & ICRG & 508 & 2.136 & 1.229 & 0 & 4 \\
Democratic Accountability & ICRG & 558 & 3.228 & 1.836 & 0 & 6 \\
Polity II & Polity IV & 843 & 0.299 & 7.496 & -10 & 10 \\
Regime Durability & Polity IV & 853 & 22.114 & 28.286 & 0 & 191 \\
Legislative Electoral Competition & DPI & 925 & 5.115 & 2.233 & 1 & 7 \\
Executive Electoral Competition & DPI & 925 & 4.923 & 2.197 & 1 & 7 \\
Fractionalization & DPI & 753 & 0.451 & 0.320 & 0 & 1 \\
Polarization & DPI & 851 & 0.340 & 0.720 & 0 & 2 \\
Checks & DPI & 888 & 2.374 & 1.656 & 1 & 11
\end{tabular}


Table 2: Factor Loadings for institutional Principle Factor Variables

\begin{tabular}{lrrrrrr}
\hline & $\begin{array}{l}\text { Dem- } \\
\text { ocracy }\end{array}$ & Trans- & Crency & ibility & \multicolumn{1}{c}{ Factor } & \multicolumn{1}{c}{$\begin{array}{r}\text { Factor } \\
\text { inique- }\end{array}$} \\
\hline Government Stability & 0.174 & 0.074 & 0.659 & -0.006 & 0.034 & 0.530 \\
nnvestment Profile & 0.344 & 0.268 & 0.663 & 0.005 & -0.035 & 0.369 \\
Corruption & 0.278 & 0.731 & -0.042 & 0.011 & -0.029 & 0.386 \\
Bureaucracy & 0.403 & 0.711 & 0.199 & 0.015 & 0.035 & 0.291 \\
Democratic Accountability & 0.624 & 0.552 & 0.134 & -0.024 & -0.033 & 0.287 \\
Polity Index & 0.840 & 0.260 & 0.008 & -0.053 & -0.190 & 0.187 \\
Regime Durability & 0.108 & 0.560 & 0.085 & -0.006 & 0.082 & 0.660 \\
Legislative Index of Electoral Competition & 0.869 & -0.088 & 0.072 & -0.123 & 0.102 & 0.207 \\
Executive Index of Electoral Competition & 0.860 & 0.014 & 0.021 & -0.161 & 0.035 & 0.234 \\
Electoral Fraud & -0.085 & -0.372 & -0.019 & -0.112 & 0.246 & 0.781 \\
Fractionalization & 0.823 & -0.012 & 0.065 & 0.205 & 0.033 & 0.276 \\
Polarization & 0.533 & 0.300 & 0.004 & 0.394 & -0.025 & 0.470 \\
Checks & 0.710 & 0.196 & -0.061 & 0.253 & 0.030 & 0.389 \\
\hline
\end{tabular}

Highlighted cells represent factor loadings greater than 0.4. 
Table 3: GMM Regression Results (Dependent Variable = High-Skilled Emigration)

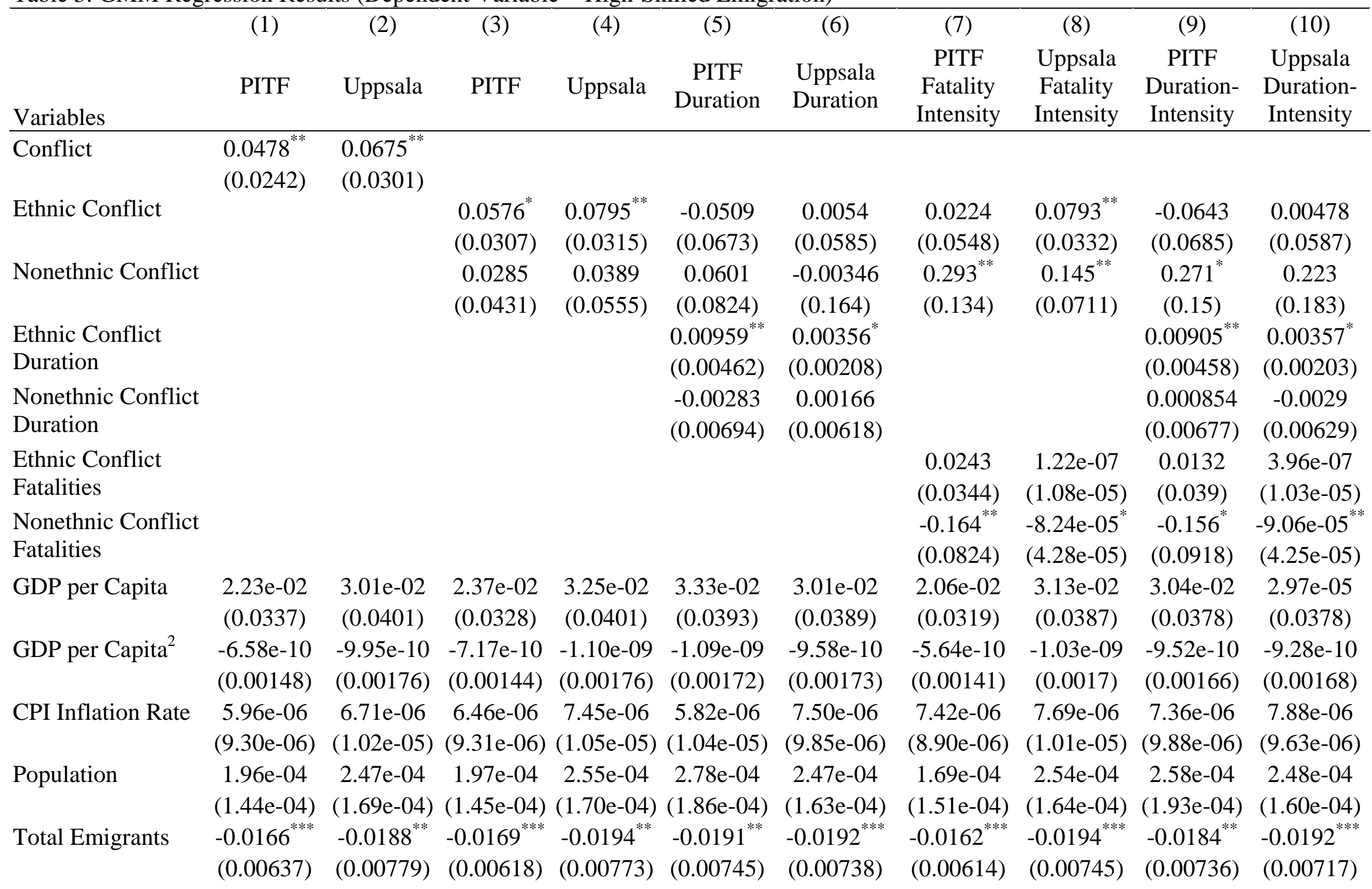


Table 3 (continued): GMM Regression Results (Dependent Variable = High-Skilled Emigration)

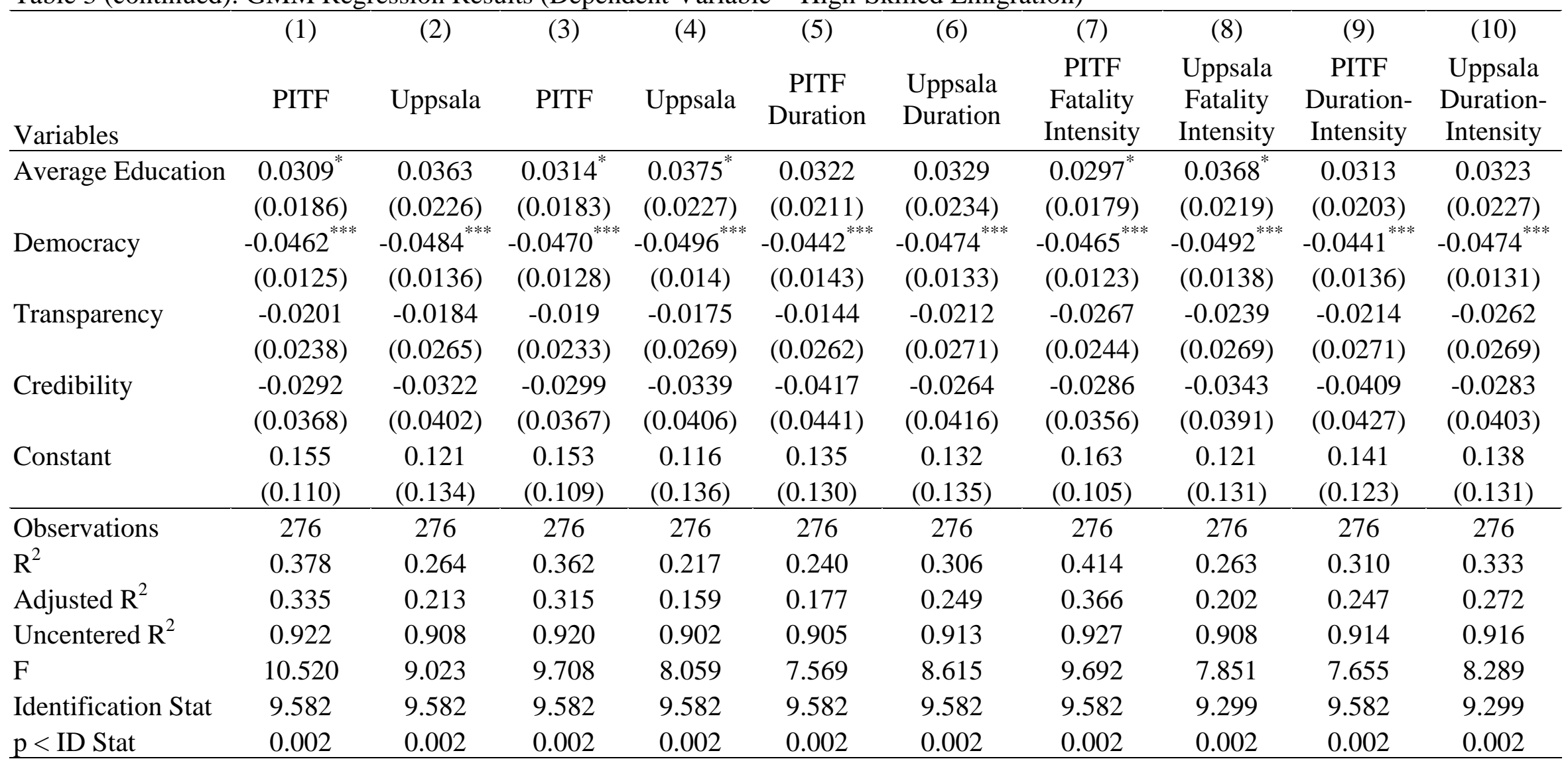

Standard errors in parentheses; ${ }^{* * *} \mathrm{p}<0.01,{ }^{* *} \mathrm{p}<0.05,{ }^{*} \mathrm{p}<0.1$

Excluded Instruments: Energy consumption per capita and energy consumption per capita squared for GDP per capita and GDP per capita squared. 


\section{Appendix}

Table A1: Matrix of Correlation Coefficients of Included Variables

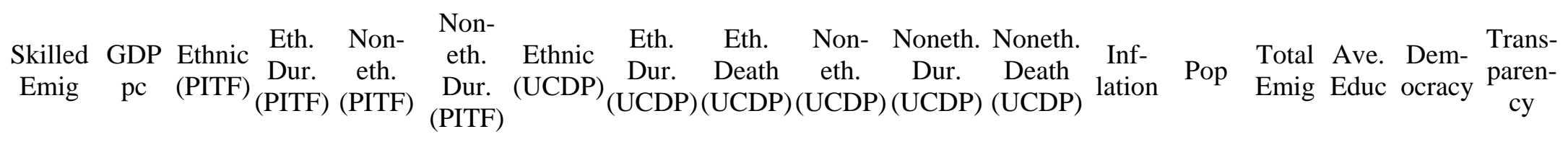

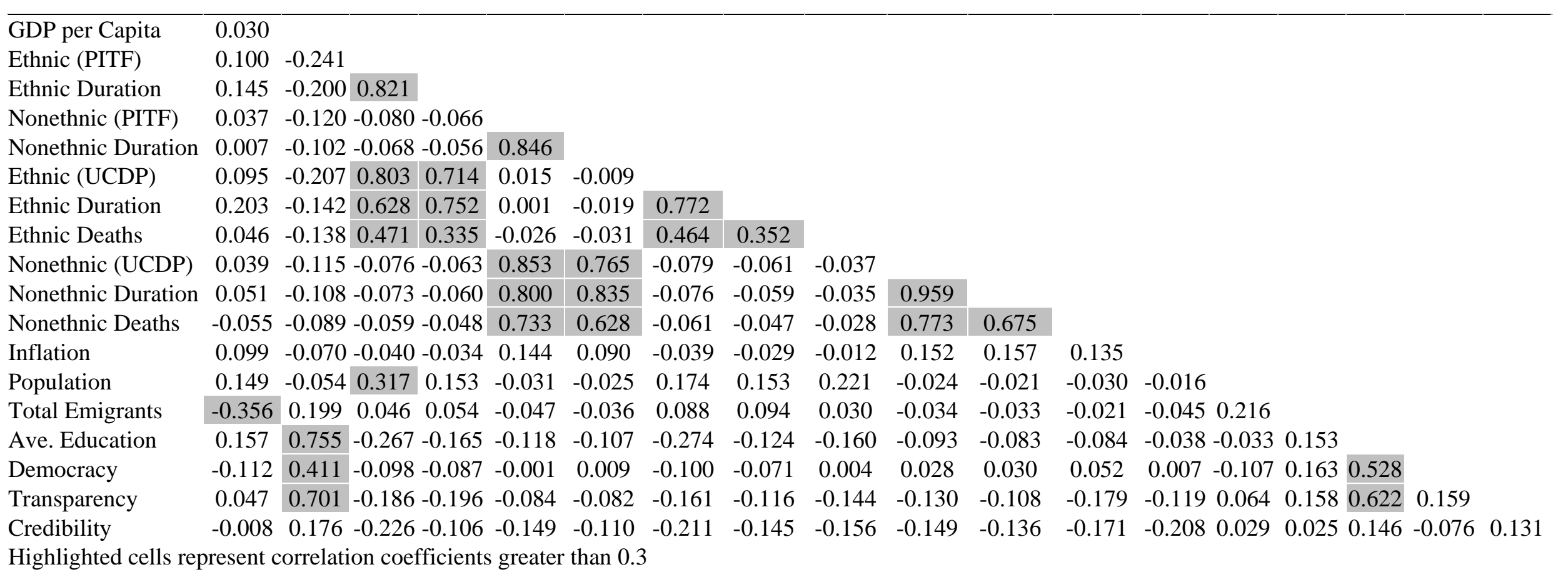


Table A2: Correlation Coefficients for Observed Institutional Variables

\begin{tabular}{|c|c|c|c|c|c|c|c|c|c|c|c|}
\hline & $\begin{array}{l}\text { Gov. } \\
\text { Stab. }\end{array}$ & $\begin{array}{l}\text { Inv. } \\
\text { Prof. }\end{array}$ & Corrupt & $\begin{array}{l}\text { Bur. } \\
\text { Qual. }\end{array}$ & $\begin{array}{l}\text { Dem. } \\
\text { Acct. }\end{array}$ & Polity & $\begin{array}{c}\text { Dur- } \\
\text { ability }\end{array}$ & LIEC & EIEC & Frac. & $\begin{array}{l}\text { Pol- } \\
\text { ariz. }\end{array}$ \\
\hline Investment Profile & 0.645 & & & & & & & & & & \\
\hline Corruption & 0.070 & 0.289 & & & & & & & & & \\
\hline Bureaucratic Quality & 0.205 & 0.390 & 0.729 & & & & & & & & \\
\hline Democratic Accountability & 0.122 & 0.314 & 0.656 & 0.645 & & & & & & & \\
\hline Polity & -0.014 & 0.186 & 0.458 & 0.449 & 0.674 & & & & & & \\
\hline Regime Durability & 0.114 & 0.236 & 0.475 & 0.520 & 0.427 & 0.205 & & & & & \\
\hline Legislative Electoral Competition & -0.042 & 0.204 & 0.254 & 0.184 & 0.435 & 0.631 & 0.078 & & & & \\
\hline Executive Electoral Competition & -0.070 & 0.158 & 0.304 & 0.274 & 0.499 & 0.788 & 0.110 & 0.710 & & & \\
\hline Political Fractionalization & 0.134 & 0.140 & 0.236 & 0.246 & 0.403 & 0.483 & -0.061 & 0.578 & 0.431 & & \\
\hline Political Polarization & 0.155 & 0.226 & 0.339 & 0.341 & 0.457 & 0.428 & 0.159 & 0.309 & 0.343 & 0.554 & \\
\hline Checks & 0.084 & 0.229 & 0.343 & 0.406 & 0.507 & 0.564 & 0.192 & 0.435 & 0.547 & 0.522 & 0.608 \\
\hline
\end{tabular}

Highlighted cells represent correlation coefficients greater than 0.3 